\title{
Multi-element composition of soil, mosses and mushrooms and assessment of natural and artificial radioactivity of a pristine temperate rainforest system (Slavonia, Croatia)
}

\author{
Maja Ivanić ${ }^{a}$, Željka Fiket ${ }^{a, *^{*}}$, Gordana Medunić ${ }^{\mathrm{b}}$, Martina Furdek Turk ${ }^{\mathrm{a}}$, \\ Gordana Marović c , Jasminka Senčar ${ }^{c}$, Goran Kniewald ${ }^{\mathrm{a}}$ \\ ${ }^{a}$ Ruđer Bošković Institute, Division for Marine and Environmental Research, Bijenička 54, 10000 Zagreb, Croatia \\ ${ }^{\mathrm{b}}$ Faculty of Science, Department of Geology, Horvatovac 95, 10000 Zagreb, Croatia \\ ${ }^{\mathrm{c}}$ Institute for Medical Research and Occupational Health, Ksaverska cesta 2, Zagreb, Croatia
}

\section{H I G H L I G H T S}

- Multi-element composition of soil, mosses and mushrooms from a pristine forest.

- Soil radioactivity levels $\left({ }^{238} \mathrm{U},{ }^{235} \mathrm{U}\right.$,

$\left.{ }^{232} \mathrm{Th}, \quad{ }^{40} \mathrm{~K}, \quad{ }^{7} \mathrm{Be},{ }^{137} \mathrm{Cs}, \quad{ }^{134} \mathrm{Cs}\right)$ determined.

- Element levels in mosses and mushrooms influenced by substrate geochemistry.

- Indications of atmospheric deposition of $\mathrm{Bi}, \mathrm{Cd}$ and $\mathrm{Pb}$.

\section{A R T I C L E I N F O}

\section{Article history:}

Received 5 July 2018

Received in revised form

9 October 2018

Accepted 16 October 2018

Available online 17 October 2018

Handling Editor: Martine Leermakers

\section{Keywords:}

metal(loid)s

Radionuclides

Soil

Plants

ICP-MS

Gamma spectrometry
G R A P H I C A L A B S T R A C T

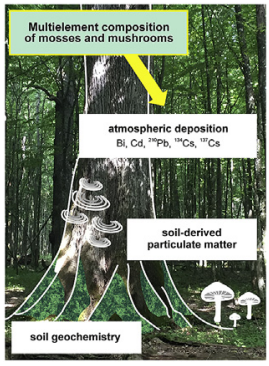

\section{A B S T R A C T}

This study investigates multi-element composition of soil, mosses and mushrooms from a pristine temperate rainforest (Prašnik, Croatia). Additionally, the activity levels of natural ${ }^{238} \mathrm{U},{ }^{235} \mathrm{U}$ and ${ }^{232} \mathrm{Th}$ decay chains, ${ }^{40} \mathrm{~K}$ and ${ }^{7} \mathrm{Be}$ ) and anthropogenic $\left({ }^{137} \mathrm{Cs}\right.$ and ${ }^{134} \mathrm{Cs}$ ) radionuclides in the investigated soil samples, obtained by gamma spectrometry, provide baseline of environmental radioactivity levels in this area. The aim of investigation was to explore the uptake of metal(loid)s by bioindicator species (mosses, mushrooms) growing in a pristine environment characterized by naturally elevated concentration of metals. The calculated enrichment and bioaccumulation factors, correlations between different groups of elements and similar multi-element patterns in mosses, mushrooms and soil samples revealed the prevailing influence of the local substrate geochemistry on element concentrations in mosses and mushrooms. The results suggest atmospheric deposition of $\mathrm{Bi}, \mathrm{Cd}$ and $\mathrm{Pb}$, while radionuclide activities point to atmospheric fall-out (including global contamination by radiocaesium) and influence of the pedological substrate. The confined area of investigation, with limited variations in soil characteristics and geological composition, allowed clearer insight into the origin of metal(loid)s in mosses and mushrooms. On the other hand, using bioindicator species with different element uptake mechanisms enabled distinction between different sources of elements.

(ㄷ) 2018 Elsevier Ltd. All rights reserved.

\footnotetext{
* Corresponding author.

E-mail address: zeljka.fiket@irb.hr (Ž. Fiket).
} 


\section{Introduction}

Origin of heavy metals in soil can be lithogenic (geological) and anthropogenic, the latter as a result of both local contamination and long-range atmospheric transport. Due to their increased input, resulting from industrial progress and various human activities (Kabata-Pendias, 2011), and persistence, heavy metals are considered as major environmental pollutants (Raj et al., 2011). Slow removal processes, e.g. leaching, erosion, plant uptake, deflation, additionally contribute to their persistence in soils (KabataPendias, 2011), from where they are easily transferred into plants and animals and can, consequently, influence human health.

Monitoring their concentration in soil is therefore an important task in the evaluation of ecological status of the environment. Biological samples (plants, fungi, mosses, lichens) have become a useful mechanism in assessing the state of the investigated environment and monitoring environmental pollution (Steinnes et al., 2011; Tuzen, 2003).

There are two main pathways through which elements accumulate in plants: atmospheric deposition and transfer from soil trough the root system; while their ratio depends on the plant physiology. Mechanisms of element uptake in mosses and mushrooms differ significantly from those found in vascular plants, allowing them to accumulate metals from the environment, which has been recognized as a promising bioremediation strategy (Chiarenzelli et al., 2001; Das, 2005; Kalač, 2010; Kalač and Svoboda, 2000; Marović et al., 2008).

Mushrooms take up elements from a substrate via mycelium that lives in soil for months or years and controls the metal content in fruiting bodies (Das, 2005; Garcia et al., 2009). Due to short lifetime of the fruiting body, atmospheric deposition as a source of metals is not considered as a factor of significance in mushrooms (Kalač and Svoboda, 2000; Kalač et al., 2004). Since the capacity of mushrooms to accumulate metals surpasses higher plants (Sesli et al., 2008; Turkekul et al., 2004; Tuzen, 2003), it can be very misleading to consider wild growing mushrooms from pristine environments as a beneficial dietary supplement on account of absence of nearby anthropogenic influences. The concentrations of metals in mushrooms is influenced by numerous factors and, along with species-specific affinities, environmental factors, e.g. substrate properties (soil geochemistry), seem to have an important role in this process (García et al., 2009; Nikkarinen and Mertanen, 2004), even though not clearly defined.

Mosses are a group of non-vascular plants with specific features (lack of root system, weakly developed cuticle, and large surfaceto-volume ratio) that allow them to take up water, nutrients and metals with their surface via wet and dry air depositions. They have become a routinely used bioindicator of atmospheric heavy metal deposition, as an easier and cheaper alternative, or a complementary monitoring tool to conventional depositional analysis (Fernandez and Carballeira, 2002; Prudêncio, 2007; Harmens et al., 2010; Klos et al., 2012; Corisco et al., 2017; Lazo et al., 2018; Markert et al., 1999; Steinnes et al., 2011). Investigations as the one carried out periodically by the International Cooperative Programme on Effects of Air Pollution on Natural Vegetation and Crops (Harmens et al., 2010, 2015), on trace elements in mosses, provide a great overview of the trends in the long-range atmospheric transport of heavy metals across Europe.

Determination of activity levels of radionuclides in soil provides baseline levels of radioactivity of a certain region necessary for monitoring purposes. The radionuclides of natural origin with long half-lives, ${ }^{238} \mathrm{U},{ }^{232} \mathrm{Th}$ and ${ }^{40} \mathrm{~K}$, are the major terrestrial sources of gamma radiation (EPA, 1999), while determination of specific activity of ${ }^{7} \mathrm{Be}$ is only recently included in soil and plant studies
(Džoljić et al., 2017). The presence of anthropogenic radiocaesium $\left({ }^{137} \mathrm{Cs}\right.$ and $\left.{ }^{134} \mathrm{Cs}\right)$ is correlated to the global contamination of biosphere, as a result of past nuclear tests and accidents. The Chernobyl accident in 1986 introduced large quantities of ${ }^{137} \mathrm{Cs}$ and ${ }^{134} \mathrm{Cs}$ that still arrive from the upper parts of the atmosphere, while the nuclear accident in Fukushima in 2011 released additional amounts of ${ }^{137} \mathrm{Cs}$ and ${ }^{134} \mathrm{Cs}$ into the environment. Monitoring radionuclide activities is, therefore, an important part of environmental protection, and crucial information in evaluating radiation exposure from environmental sources (Durusoy and Yildirim, 2017).

Environments free of human influence offer a rare opportunity to study the fractionation of metal(loid)s in the soil-moss/ mushroom system. The present study was performed in a protected area of a temperate rainforest, the last remnant of the Slavonian (Croatia) rainforest (Mesić Kiš et al., 2016). This pristine soilplant system is optimal for establishing baseline concentrations of metal(loid)s and radionuclides in an area free of nearby anthropogenic point sources.

Due to great biological importance, Prašnik rainforest was excluded from human activities since 1928. In addition, for two decades this area was prohibited for visitors on account of risk from land mines placed during the 1990s war in Croatia, leaving only contaminants arriving by air and water as potential sources of contamination. Mesić Kiš et al. (2016) established only slight and locally restricted influence of the war activities on the soil geochemistry. The first part of this research investigated rare earth fingerprints in the soil of the Prašnik rainforest, and their uptake by mosses and mushrooms (Fiket et al., 2017a). Elevated levels of rare earth elements (REE), established in the investigated species, were primarily influenced by the pedological setting (Fiket et al., 2017a). The present study considers determination of sources of metal(loid)s and their distribution in the two established biomonitoring groups of organisms, mosses and mushrooms, in a pristine forest environment characterized by naturally elevated REE levels.

The main objective of this study was, therefore, to: (i) assess the influence of the pedological substrate on the composition of metal(loid)s in mosses and mushrooms, as sensitive bioindicators of air quality and environmental health, (ii) determine the natural radionuclide activities in soil of the Prašnik forest, and (iii) establish the influence of long-range atmospheric emissions on the investigated forest environment.

This was accomplished by a complete multi-element analysis of soil, moss and mushroom samples and determination of natural $\left({ }^{40} \mathrm{~K},{ }^{238} \mathrm{U},{ }^{232} \mathrm{Th},{ }^{235} \mathrm{U},{ }^{7} \mathrm{Be}\right)$ and artificial $\left({ }^{137} \mathrm{Cs},{ }^{134} \mathrm{Cs}\right)$ radionuclide activities in soil samples from a pristine environment of the Prašnik rainforest.

\section{Materials and methods}

\subsection{Study area}

Prašnik forest is the last remnant of the Slavonia rainforest (Fiket et al., 2017a), located in eastern part of Croatia (Fig. 1a and b). With its 300-years old oak trees, the forest is of great biological significance and as such was proclaimed in 1965 as a special forest vegetation reserve. It was only recently opened for visitors due to the landmine presence since the war in 1990s. A detailed geological and pedological description is given elsewhere (Mesić Kiš et al., 2016; Šparica et al., 1984). Briefly, the study area comprises mostly Quaternary alluvial deposits with Pseudogley deposits, or carbonate-reduced loess, as the dominant lithological unit (Bašić, 2013). 


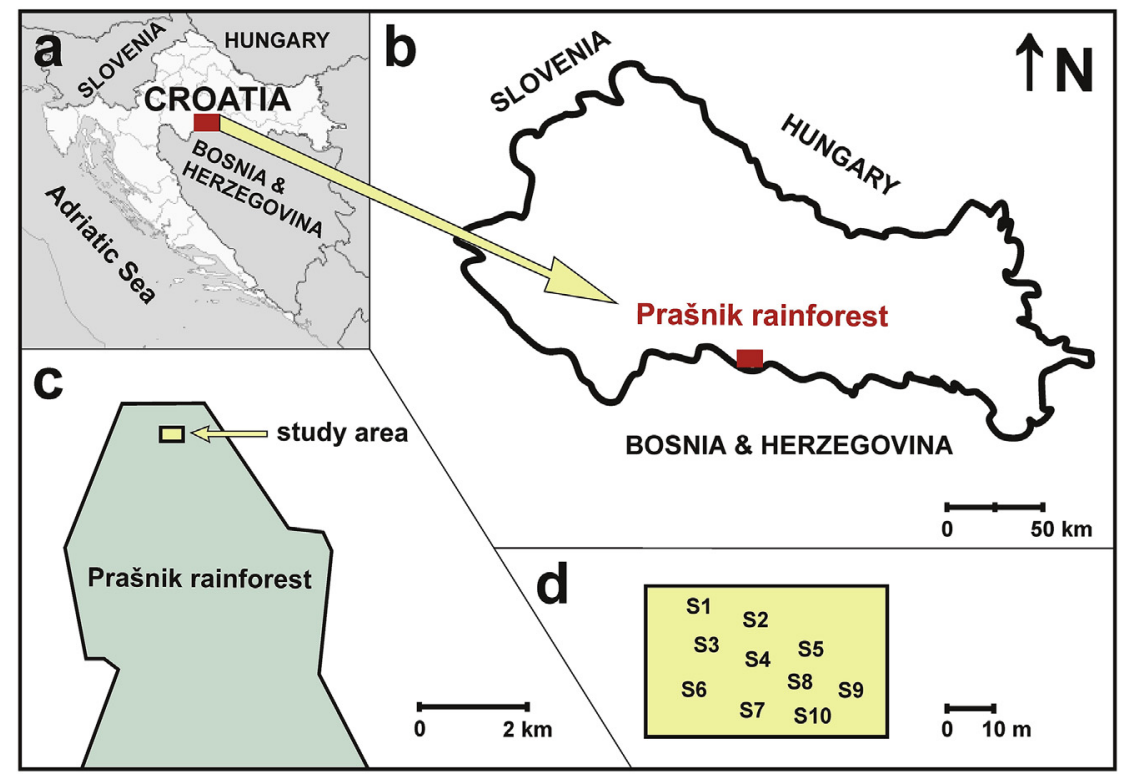

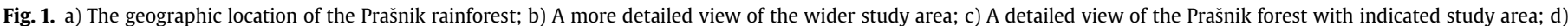
Distribution of sampling locations.

\subsection{Sample collection and preparation}

Soil (S1-S10) and moss (M1-M10) samples were collected at ten locations within $1500 \mathrm{~m}^{2}$ of the North Prašnik forest (Fig. 1c and d), as described in Fiket et al. (2017a). Soil samples represent the topsoil layer $(0-20 \mathrm{~cm})$, while moss samples were collected from tree trunks at a height of approximately $0.5-1 \mathrm{~m}$. In the laboratory, soil samples were sieved through a $2 \mathrm{~mm}$ sieve and mosses were manually cleaned of soil particles, plant remains and epiphytes. Two types of aboveground mushrooms were chosen according to their living habits: Agaricus sp., growing on soil (location S1) and Trichaptum biformel, growing on a tree trunk (location S3). All samples were air-dried $\left(20^{\circ} \mathrm{C}\right)$, homogenised using an agate mill and stored for further analysis.

\subsection{Characterization of soil samples}

The granulometric characterization of soil samples was performed using laser diffraction on LS 13320 (Beckman Coulter, USA). Prior to measurement, soil samples were soaked in deionized water overnight and treated with ultrasound for $5 \mathrm{~min}$. The particle size was classified according to the modified Wentworth (1922) grade scale with the clay-silt boundary at $2 \mu \mathrm{m}$. The soil properties referred to in this paper: loss on ignition (LOI), specific surface area (SSA), cation exchange capacity (CEC) as well as the sum of REE ( $\sum$ REE) in moss and soil samples (Table 2), are from Fiket et al. (2017a).

\subsection{Multi-element analysis}

Prior to multi-element analysis, subsamples $(0.05 \mathrm{~g})$ of soils were subjected to total digestion in the microwave oven (Multiwave 3000 , Anton Paar) in a two-step procedure consisting of digestion with a mixture of $4 \mathrm{~mL}$ nitric acid $\left(\mathrm{HNO}_{3}, 65 \%\right.$, pro analysi), $1 \mathrm{~mL}$ hydrochloric acid ( $\mathrm{HCl}, 36.5 \%$, pro analysi) and $1 \mathrm{~mL}$ hydrofluoric acid (HF, 48\%, pro analysi), followed by addition of $6 \mathrm{~mL}$ boric acid $\left(\mathrm{H}_{3} \mathrm{BO}_{3}\right)$ (Fiket et al., 2017b). After digestion, soil samples were further diluted 10 -fold, acidified with $2 \%$ (v/v) $\mathrm{HNO}_{3}$ (65\%, supra pur), and indium (In, $1 \mu \mathrm{g} \mathrm{L}^{-1}$ ) was added as internal standard.

Subsamples $(0.1 \mathrm{~g})$ of mosses and mushrooms were subjected to digestion with $7 \mathrm{~mL}$ of $\mathrm{HNO}_{3}$ (65\%, supra pur) and $0.1 \mathrm{~mL}$ of $\mathrm{HF}(48 \%$, pro analysi) (Filipović Marijić and Raspor, 2012). Similarly to soil samples, mosses and mushrooms digests were acidified with $2 \%(\mathrm{v} /$ v) $\mathrm{HNO}_{3}(65 \%$, supra pur), but without further dilution and indium (In, $1 \mu \mathrm{g} \mathrm{L}^{-1}$ ) was added as internal standard.

The multi-element analysis was performed by High Resolution Inductively Coupled Plasma Mass Spectrometry (HR-ICP-MS) using an Element 2 instrument (Thermo, Bremen, Germany). The instrument conditions and measurement parameters used throughout the work have been reported in Fiket et al. (2017b). Standards for multi-element analysis were prepared by appropriate dilution of a multi-elemental reference standard (Analytika, Prague, Czech Republic) containing $\mathrm{Al}, \mathrm{As}, \mathrm{Be}, \mathrm{Cd}, \mathrm{Co}, \mathrm{Cr}, \mathrm{Cu}, \mathrm{Fe}, \mathrm{Li}, \mathrm{Mn}$, $\mathrm{Ni}, \mathrm{Pb}, \mathrm{Rb}, \mathrm{Sr}$ and $\mathrm{Ti}$ in which single element standard solutions of Sn (Analytika, Prague, Czech Republic) and Sb (Analytika, Prague, Czech Republic) were added. Samples were analysed for the total concentration of 27 elements ( $\mathrm{Al}, \mathrm{As}, \mathrm{Ba}, \mathrm{Be}, \mathrm{Bi}, \mathrm{Cd}, \mathrm{Co}, \mathrm{Cr}, \mathrm{Cs}, \mathrm{Cu}, \mathrm{Fe}$, $\mathrm{Li}, \mathrm{Mn}, \mathrm{Mo}, \mathrm{Ni}, \mathrm{Pb}, \mathrm{Rb}, \mathrm{Sb}, \mathrm{Sc}, \mathrm{Sn}, \mathrm{Sr}, \mathrm{Ti}, \mathrm{Tl}, \mathrm{U}, \mathrm{V}, \mathrm{Zn}$ and $\mathrm{Zr}$ ). The quality control of analytical procedure was performed by a simultaneous analysis of the blank sample and the certified reference material for soil (NCS DC 77302, also known as GBW 07410, China National Analysis Centre for Iron and Steel, Beijing, China) and Rye grass (ERM-CD281). A good agreement between the analysed and the certified concentrations (analytical uncertainties <10\%) was obtained for all measured elements.

The bioaccumulation factors (BAF) were calculated as follows:

$\mathrm{BAF}=\mathrm{C}_{\text {moss or mushroom }} / \mathrm{C}_{\text {soil }} ;(\mathrm{C}=$ concentration $)$

The enrichment factors (EF) were calculated using $\sum$ REE (from Fiket et al., 2017a) as a marker of particulate deposition according to equation:

$\mathrm{EF}=\left(\mathrm{Cx} / \mathrm{C}_{\sum \mathrm{REE}}\right) \operatorname{moss} /\left(\mathrm{Cx} / \mathrm{C}_{\sum \mathrm{REE}}\right)$ soil 


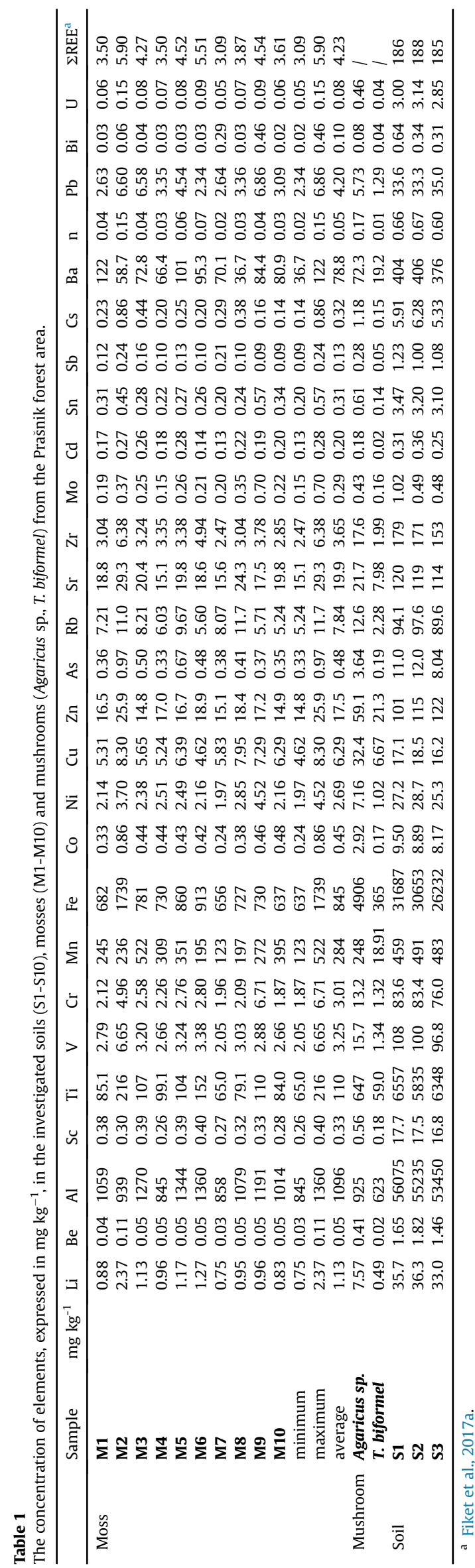

Table 2

The share of clay, silt and sand fraction, and the Mean size (Mz) of the investigated soil samples. The results on LOI (lost on ignition), CEC (cation exchange capacity) and SSA (specific surface area) are from Fiket et al. (2017a).

\begin{tabular}{llllllll}
\hline Sample & $\begin{array}{l}\text { Clay } \\
(\text { vol. \%) }\end{array}$ & $\begin{array}{l}\text { Silt } \\
(\text { vol. \%) }\end{array}$ & $\begin{array}{l}\text { Sand } \\
(\text { vol. \%) }\end{array}$ & $\begin{array}{l}\mathrm{Mz} \\
(\mu \mathrm{m})\end{array}$ & $\begin{array}{l}\mathrm{LOI}^{\mathrm{a}} \\
(\text { wt. \%) }\end{array}$ & $\begin{array}{l}\mathrm{CEC}^{\mathrm{a}} \\
\left(\mathrm{cmol}_{+} \mathrm{kg}^{-1}\right)\end{array}$ & $\begin{array}{l}\mathrm{SSA}^{\mathrm{a}} \\
\left(\mathrm{m}^{2}{ }^{-1}\right)\end{array}$ \\
\hline S1 & 11.9 & 77.2 & 10.9 & 29.3 & 9.14 & 25.6 & 8.00 \\
S2 & 8.60 & 70.5 & 20.9 & 50.3 & 15.7 & 28.9 & 5.58 \\
S3 & 8.20 & 66.1 & 25.7 & 74.6 & 8.07 & 24.2 & 7.14 \\
S4 & 10.9 & 77.6 & 11.5 & 35.4 & 10.0 & 22.8 & 6.61 \\
S5 & 8.90 & 70.4 & 20.7 & 62.1 & 10.9 & 22.0 & 6.60 \\
S6 & 10.2 & 77.2 & 12.6 & 36.9 & 7.21 & 17.6 & 8.92 \\
S7 & 6.70 & 66.6 & 26.7 & 70.0 & 12.4 & 26.5 & 5.33 \\
S8 & 10.4 & 78.4 & 11.2 & 34.3 & 10.2 & 16.1 & 6.81 \\
S9 & 11.1 & 81.9 & 7.00 & 23.8 & 6.79 & 16.2 & 9.78 \\
S10 & 12.9 & 75.5 & 11.6 & 28.6 & 11.0 & 29.4 & 6.98 \\
\hline
\end{tabular}

a Fiket et al., 2017a.

\subsection{Measurements of radionuclide activities}

Measurements and calculations of activity concentrations in soil samples were performed using a high-resolution gamma-ray spectrometry. The activity of a sample was measured using a coaxial high purity Ge detector (Ortec GMX with a relative efficiency of $74.2 \%$ and resolution of $2.24 \mathrm{keV}$, all referring to $60 \mathrm{Co}$ at $1.33 \mathrm{MeV}$ ) and/or a coaxial $\mathrm{Ge}(\mathrm{Li})$ detector (also Ortec with a relative efficiency of $16.8 \%$ and resolution of $1.78 \mathrm{keV}$, all referring to $60 \mathrm{Co}$ at $1.33 \mathrm{MeV}$ ). All necessary calculations were performed using Ortec GammaVision software.

Counting time was $80000 \mathrm{~s}$ or higher, depending on sample activities. Energy and efficiency calibration procedures were performed with Czech Metrology Institute (CMI) certified standards. Quality assurance and intercalibration measurements were performed through participation in an International Atomic Energy Agency (IAEA), World Health Organization (WHO) and Joint Research Centre (JRC) international intercalibration programs.

The radium equivalent activity, $\mathrm{Ra}_{\mathrm{ekv}}\left(\mathrm{Bq} \mathrm{kg}^{-1}\right)$, enables comparison of specific activities of materials containing different amounts of ${ }^{226} \mathrm{Ra},{ }^{232} \mathrm{Th}$ and ${ }^{40} \mathrm{~K}$ and assumes that $1 \mathrm{~Bq} \mathrm{~kg}^{-1}$ of ${ }^{226} \mathrm{Ra}, 0.7 \mathrm{~Bq} \mathrm{~kg}{ }^{-1}$ of ${ }^{232} \mathrm{Th}$ and $13 \mathrm{~Bq} \mathrm{~kg}^{-1}$ of ${ }^{40} \mathrm{~K}_{\text {produce the same }}$ gamma ray dose rate. It was calculated for soil samples according to equation of Beretka and Mathew (1985):

$R a_{e k v}=A(R a)+1.43 \times A(T h)+0.077 \times A(K)$

where $A(R a), A(T h)$ and $A(K)$ are the mean activity concentrations of ${ }^{226} \mathrm{Ra},{ }^{232} \mathrm{Th}$ and ${ }^{40} \mathrm{~K}$ in Bq kg${ }^{-1}$, respectively.

The external hazard index, $\mathrm{H}_{\mathrm{ex}}$, correlates to the radium equivalent activity of $370 \mathrm{~Bq} \mathrm{~kg}^{-1}$ and it was calculated according to the following equation:

$H_{e x}=\frac{A(R a)}{370}+\frac{A(T h)}{259}+\frac{A(K)}{4810} \leq 1$

where $A(R a), A(T h)$ and $A(K)$ are the activity concentrations of ${ }^{226} \mathrm{Ra},{ }^{232} \mathrm{Th}$ and ${ }^{40} \mathrm{~K}$.

\section{Results and discussion}

3.1. Multi-element composition of soil, moss and mushroom samples of the Prašnik forest

The investigated pristine forest environment is, according to the FOREGS geochemical atlas (Salminen et al., 2005), characterized by naturally elevated levels of $\mathrm{Al}, \mathrm{Be}, \mathrm{Bi}, \mathrm{Co}, \mathrm{Cr}, \mathrm{Cs}, \mathrm{Cu}, \mathrm{Fe}, \mathrm{Mo}, \mathrm{Ni}, \mathrm{Rb}, \mathrm{Sb}$, 
Sc, Sn, Ti, U, V, Zn, Zr and REE. This provides an interesting study area for widening the knowledge on the distribution of elements between soil and non-vascular bioindicator species.

In the investigated area, the measured element concentrations ranged from $0.02 \mathrm{mg} \mathrm{kg}^{-1}$ to $1.7 \mathrm{~g} \mathrm{~kg}^{-1}$ in mosses, from $0.01 \mathrm{mg} \mathrm{kg}^{-1}$ to $4.9 \mathrm{~g} \mathrm{~kg}^{-1}$ in mushrooms and from $0.23 \mathrm{mg} \mathrm{kg}^{-1}$ to $56 \mathrm{~g} \mathrm{~kg}^{-1}$ in soils. In general, the element levels in mosses and mushrooms were one to two orders of magnitude lower compared to soil samples (Table 1 ). The exception was $\mathrm{Cu}$ with higher values determined in the Agaricus sp. (32.4 $\mathrm{mg} \mathrm{kg}^{-1}$ ) compared to its soil content in any location. In general, the largest differences in element concentrations were observed between T. biformeI and soil, the smallest between Agaricus sp. and soil, while moss samples were in between.

\subsubsection{Soil characteristics and multi-element composition}

The results revealed predominance of silt-sized particles (66-82\%), with the mean size (Mz) from $24 \mu \mathrm{m}$ to $74.6 \mu \mathrm{m}$ (Table 2). The content of clay in the investigated soils was low $(<13 \%)$.

Considering limited area of investigation, elements in the investigated soil samples mostly occurred in a narrow range of values, except for the more varying concentrations obtained for As, $\mathrm{Bi}, \mathrm{Co}, \mathrm{Cu}, \mathrm{Mn}$, Mo and $\mathrm{Zn}$ (with RSD from 24\% to 34\%; Table 1). The minimal concentrations of all elements, except Mn, were determined in station S7. This could be associated with the smallest share of clayey particles determined at this location (Table 2), up to two times lower than in some other locations.

The concentrations of metal(loid)s in soil samples were mostly in agreement with the data reported by FOREGS (Salminen et al., 2005), except for the lower concentrations of $\mathrm{Al}, \mathrm{Co}, \mathrm{Cr}, \mathrm{Ni}, \mathrm{Sn}, \mathrm{Zr}$ and slightly higher levels of $\mathrm{Cd}, \mathrm{Pb}$ and $\mathrm{Zn}$ (Table 1 ). The concentrations of $\mathrm{Cd}, \mathrm{Cu}, \mathrm{Fe}, \mathrm{Mn}$ and $\mathrm{Ni}$ corresponded to those reported by Mesić Kiš et al. (2016) for the Prašnik area, while $\mathrm{Cr}$, Pb and $\mathrm{Zn}$ were slightly higher.

To assess the origin of elements in the studied soils, the correlation coefficients (Table S1, SI) were calculated between the obtained element concentrations, including the previously reported $\sum$ REE and soil characteristics (Table 2, Fiket et al., 2017a). The group of litophile elements, $\mathrm{Al}, \mathrm{Be}, \mathrm{Cs}, \mathrm{Li}, \mathrm{Rb}$, and $\mathrm{Sc}$, showed statistically significant strong positive correlations with $\mathrm{Cd}, \mathrm{Cr}, \mathrm{Cu}, \mathrm{Fe}$, $\mathrm{Ni}$ and $\mathrm{Tl}$ (from 0.65 to $0.95, \mathrm{p}<0.05$ ) and the $\sum \mathrm{REE}$ (from 0.70 to $0.86, \mathrm{p}<0.05$ ). The $\mathrm{Cr}$, Ti and $\mathrm{Zr}$, although readily bound to heavy mineral fraction in soil, showed lack of correlation with this group of elements, and were found positively correlated with $\mathrm{Co}, \mathrm{Mo}, \mathrm{Pb}$, $\mathrm{Sb}, \mathrm{Sn}$ and $\mathrm{V}$ (from 0.65 to $0.93, \mathrm{p}<0.05$ ). The listed elements exhibited also positive correlations within the group itself (from 0.66 to $0.94, \mathrm{p}<0.05$ ) and As (from 0.67 to $0.88, \mathrm{p}<0.05$ ). Additionally, the $\mathrm{Mz}$ and sand content were found to be negatively correlated with the latter group of elements (from -0.64 to -0.78 , $\mathrm{p}<0.05$ ), while SSA, on the other hand, exhibited strong positive correlations with these elements and Fe (from 0.64 to 0.77 , $\mathrm{p}<0.05$ ). The latter suggests predominance of these elements (Co, $\mathrm{Cr}$, Fe, Mo, $\mathrm{Pb}, \mathrm{Sb}, \mathrm{Sn}, \mathrm{Ti}, \mathrm{V}$ and $\mathrm{Zr}$ ) in the fine-grained fraction of soils. Positive correlations were also found for $\mathrm{U}$ and $\mathrm{Sr}$ (from 0.64 to $0.86, \mathrm{p}<0.05$ ) and several elements ( $\mathrm{Al}, \mathrm{As}, \mathrm{Cr}, \mathrm{Fe}, \mathrm{Sc}, \mathrm{Sn}, \mathrm{Zr}, \mathrm{Ti}, \mathrm{Tl}$ and $\sum$ REE), while Ba exhibited positive correlation with $\mathrm{Sr}$ and elements of the first group, $\mathrm{Cd}$ and $\mathrm{Be}(0.67$ and 0.82 , respectively, $\mathrm{p}<0.05$ ). Manganese showed positive correlation only with Co, while $\mathrm{Zn}$ could not be pinpointed to any group of elements. Given the geological complexity of this area (Mesić Kiš et al., 2016), grouping of elements points to their association with different mineral phases, aluminosilicates, dense mineral fraction, etc. Although levels of $\mathrm{Cd}, \mathrm{Pb}$ and $\mathrm{Zn}$ slightly exceed those given in FOREGS for this area, whereby $\mathrm{Cd}$ and $\mathrm{Pb}$ in surface soils are usually linked to atmospheric deposition (Steinnes and Lierhagen, 2018), anthropogenic influence cannot be deduced from the observed relations between elements. It can be concluded that the element composition of Prašnik soils is predominately influenced by natural factors, its pedological and geological background.

\subsubsection{Multi-element composition of mosses}

The investigated epiphytic mosses showed a significantly wider range of concentrations compared to soils, with the largest variations found for Bi, Cs, Mo and Tl (RSD between 55\% and 144\%; Table 1).

In 2005-2006, Croatia joined the periodically performed moss survey conducted by the International Cooperative Programme on Effects of Air Pollution on Natural Vegetation and Crops, conducted since the 1990s (Harmens et al., 2010; Śpirić et al., 2013). Compared to the values reported by Harmens et al. (2010) for mosses in Croatia for the year 2005, the obtained results showed lower average concentrations for $\mathrm{Al}, \mathrm{Cd}, \mathrm{Cu}, \mathrm{Fe}, \mathrm{Sb}$ and $\mathrm{Zn}$ (by a factor of $1.2-1.7$ ), higher for $\mathrm{Pb}$ (by a factor of 1.3 ), and were in agreement for As, $\mathrm{Cr}$, Ni and V.

\subsubsection{Contribution of different sources on element concentrations in mosses}

Aboal et al. (2010) summarized the three types of element contribution in mosses: atmospheric (anthropogenic influence), edaphic (windblown soil particles) and plant inputs (leaching). Local soil contamination, in that sense, is considered as a significant contributor to the chemical composition of mosses (Aboal et al., 2010; Bargagli et al., 1995; Steinnes, 1995). According to Reimann et al. (2001a), high values and strong positive correlations of $\mathrm{Al}$ and $\mathrm{Fe}$ (and $\mathrm{Zr}$ ) in mosses are a good indication of the mineral dust influence on the moss element composition. Accordingly, mosses from Prašnik forest showed high values of typical geogenic elements, i.e. Al, Fe and $\mathrm{Zr}$ (Table 1). Moreover, a significant positive correlation (Table S2, SI) was established for As, Cr, V, U and Be, Fe, $\mathrm{Li}, \mathrm{Ti}, \mathrm{Tl}$ and $\mathrm{Zr}$ (from 0.65 to $0.98, \mathrm{p}<0.05$ ), also of soil borne origin, confirming importance of the local dust, or the soil factor, as a source of metals in mosses (Steinnes, 1995). The latter is further supported by their high correlation with $\sum$ REE (from 0.69 to 0.89 , $\mathrm{p}<0.05$ ), whose origin in the studied mosses was prevalently linked to local soils (Fiket et al., 2017a). Interestingly, Al and Sc displayed also strong positive correlation $(0.94, \mathrm{p}<0.05)$, but no additional elements showed grouping with them (Table S2, SI).

To assess contributions of different sources of metals in mosses, some authors propose normalization to an element of known source and conservative behaviour (Klos et al., 2012). For the soil substrate contribution, Al (Sardans and Peñuelas, 2005) or Sc (Lazo et al., 2018; Shotyk et al., 2016) are used as tracers, while Chiarenzelli et al. (2001) recommends using REE as normalizing elements for the atmospheric particle deposition. Chiarenzelli et al. (2001) found that, unlike vascular plants, mosses and lichens showed positive correlation with the $\sum$ REE due to significant role of particulate deposition on their uptake of metals, i.e. through the uplifted soil dust particles deposited on the moss surface. However, we found that normalization to both $\mathrm{Al}$ and $\sum \mathrm{REE}$ showed enrichment of the same elements, with the exception of lower EF obtained for majority of elements using $\sum$ REE as a normalizing factor. Considering $\sum$ REE as a normalizing factor, a considerable enrichment (EF 3-10) was found sporadically for Bi, Cs (in M2-M3, M7-M8) Ni, Pb, Rb, Sb, Sn, Sr, Tl (in M1-M2, M5-M6) and Zn. Even higher $\mathrm{EF}(>10)$ were determined for Ba (M1, M5, M7, M10), Bi (M7, M9), Cd, Cu (except M6), Mn and Mo, suggesting sources other than particulate deposition for these elements. Despite their high EFs, plant nutrients, $\mathrm{Co}, \mathrm{Cu}, \mathrm{Mn}, \mathrm{Ni}$ and $\mathrm{Zn}$, showed lack of correlations 
both with each other and with other elements. It is known that the important role of nutrients in life functions in plants leads to their variable plant uptake, depending on the physiological needs of mosses (Aboal et al., 2010), which could explain the lack of correlation between these elements. In addition, $\mathrm{Ba}$ and $\mathrm{Bi}$ also showed lack of correlation with other elements. This can be a consequence of variable leaching processes and/or atmospheric deposition. Increased EFs obtained for $\mathrm{Rb}$ compared to the remaining litophile elements could, on the other hand, result from its similarity with $\mathrm{K}$ (Reimann et al., 2001a). A similar explanation could also be valid for Cd and Zn (Steinnes, 1995). A positive correlation was also found for $\mathrm{Cd}$ and $\mathrm{Cu}, \mathrm{Mo}, \mathrm{Pb}$ and $\mathrm{Sr}$ (from 0.64 to $0.84, \mathrm{p}<0.05$ ), and not with the soil-borne elements. This could support its vegetation origin and/or, due to its correlation with $\mathrm{Pb}$, atmospheric contribution. Namely, an increased content of $\mathrm{Pb}$, not correlated with $\mathrm{Al}$ or $\mathrm{Zr}$, suggests long-range air pollution. According to Sardans and Peñuelas (2005), the content of $\mathrm{Pb}$ and $\mathrm{Cd}$ in tissues of plants, even in remote areas, is considered to derive from atmospheric deposition. Moreover, these authors reported enrichment of $\mathrm{Cd}, \mathrm{Cu}$, $\mathrm{Pb}, \mathrm{Sb}$ and $\mathrm{Zn}$ in plant tissues, and highlight that even though the soil factor is of significance for the metal uptake by mosses, this needs not to be reflected in the proportional soil and moss concentrations. Namely, due to different chemical behaviour of elements in soil, depending on the soil properties, variations in moss composition can be observed between different locations that are not necessarily caused by atmospheric inputs.

In addition to high $\mathrm{EF}$ of $\mathrm{Bi}, \mathrm{Mn}$ and Mo found in mosses, both soil and moss samples showed varying concentrations of these elements. According to Reimann et al. (2001b), large variability of element suggests its unusual source. It should be considered that these variations result from processes such as atmospheric deposition and/or leaching from plants, affecting both surface soil and mosses, and are not a direct result of element uptake by mosses (Reimann et al., 2001b).

When comparing elements concentrations in the investigated plants, it can be observed that moss samples showed higher average concentrations of $\mathrm{Al}, \mathrm{Ba}, \mathrm{Bi}, \mathrm{Cd}$ and $\mathrm{Mn}$, compared to mushrooms (Table 1). This can be related to higher influence of particulate deposition as a source of elements in mosses, whether from anthropogenic sources or the windblown soil dust.

\subsubsection{Mushroom element composition}

Mushrooms from the genus Agaricus are known to accumulate metals, with considerably higher concentrations found in the wildgrowing species (Kalač and Svoboda, 2000). The T. biformeI, on the other hand, is a saprotrophic mushroom, with the content of metals depending on their concentration in the host tree. Accordingly, lower values of all metals were found in T. biformeI, compared to the Agaricus sp. The largest difference in concentrations of metal(loid)s between the two mushrooms was observed for As, Be, Co, Fe, Li, Mn, $\mathrm{Ti}, \mathrm{Tl}, \mathrm{U}$ and $\mathrm{V}$ (by a factor 11 to 26); somewhat lower for Cd, Cr, Cs, $\mathrm{Ni}, \mathrm{Rb}, \mathrm{Sb}$ and $\mathrm{Zr}$ (by a factor 6 to 10); while $\mathrm{Al}, \mathrm{Ba}, \mathrm{Bi}, \mathrm{Cu}, \mathrm{Mo}, \mathrm{Pb}, \mathrm{Sc}$, $\mathrm{Sn}, \mathrm{Sr}$ and $\mathrm{Zn}$ showed the lowest differences (by a factor 1 to 5 ).

Compared to the values collected in the review of Kalač and Svoboda (2000), mushrooms from the Prašnik forest contain higher concentrations of $\mathrm{Cr}, \mathrm{Fe}, \mathrm{Mn}$ and $\mathrm{Ni}$. However, it was previously highlighted that concentrations of numerous elements in soil of the investigated area, including $\mathrm{Cr}$, $\mathrm{Fe}$ and $\mathrm{Ni}$, are naturally elevated, explaining their higher level in the studied mushrooms. The content of $\mathrm{Pb}\left(5.73 \mathrm{mg} \mathrm{kg}^{-1}\right)$ in the studied mushrooms was also higher than the values previously reported for different mushroom species (Nikkarinen and Mertanen, 2004; Sesli et al., 2008; Širić et al., 2016a; b; Turkekul et al., 2004; Tuzen, 2003) and at the upper limit of concentrations usual for mushrooms from unpolluted sites, e.g. $5 \mathrm{mg} \mathrm{kg}^{-1}$ (Kalač, 2010). The uptake of Pb with soil particles by plants is considered to be highly limited (Mabit et al., 2014), and in mushrooms is mostly found in lower concentrations and of atmospheric origin (Gadd, 2007). The obtained results could, therefore, indicate long-distance atmospheric transfer, affecting the surficial soil and plant concentrations in the area.

Contrary to mosses, the influence of soil geochemistry on the content of metal(loid)s in mushrooms cannot be clearly discerned. Nikkarinen and Mertanen (2004) found samples of the same species with considerably different content of trace elements in areas with different geochemical fingerprint, while Gast et al. (1988) and Mendil et al. (2005) consider the soil characteristics ( $\mathrm{pH}$ and organic matter content) less important for the content of metals in mushrooms.

\subsubsection{Bioaccumulation in mosses and mushrooms}

The bioaccumulation factors, or the soil uptake factors (Reimann et al., 2001a), represent the ratio of concentration of an element in plant to that in the soil sample. The calculated BAFs (Table S3, SI) were generally lower than 1 , and exceeded 1 only sporadically; for $\mathrm{Mn}$ (1.08) and $\mathrm{Cd}$ (1.05) in sample M3, and for Bi in samples M7 (1.29) and M9 (1.53). It should be highlighted that their values in the corresponding soil samples were among the lowest of all locations (Table 1). In mushrooms, only $\mathrm{Cu}$ in the Agaricus sp. showed BAF 1.75 .

In general, the lowest BAFs $(0.009-0.412)$ were found in T. biformeI, somewhat higher $(0.01-1.53)$ in mosses, while in the Agaricus sp. they were by an order of magnitude higher (0.016-1.895).

The lowest BAFs ( $<0.1$ in mosses and T. biformel; $<0.5$ in Agaricus sp.) were determined for the geogenic elements ( $\mathrm{Al}, \mathrm{As}, \mathrm{Be}, \mathrm{Co}, \mathrm{Cr}$, $\mathrm{Cs}, \mathrm{Fe}, \mathrm{Li}, \mathrm{Rb}, \mathrm{Sb}, \mathrm{Sc}, \mathrm{Sn}, \mathrm{Sr}, \mathrm{Ti}, \mathrm{Tl}, \mathrm{U}, \mathrm{V}$ and $\mathrm{Zr}$ ). In this range were also $\mathrm{BAFs}$ of $\mathrm{Ba}, \mathrm{Ni}$, and $\mathrm{Pb}$ in mushrooms, $\mathrm{Cd}$ and $\mathrm{Mn}$ in T. biformel and $\mathrm{Bi}$ and Mo in Agaricus sp. Slightly higher BAFs, between 0.1 and 0.5 , were obtained for $\mathrm{Bi}, \mathrm{Cu}, \mathrm{Mo}$ and $\mathrm{Zn}$ in mosses and T. biformel, and $\mathrm{Ba}, \mathrm{Ni}, \mathrm{Mn}, \mathrm{Pb}$ and $\mathrm{Sr}$ in mosses (in T. biformel BAFs for these elements were $<0.1)$. The highest BAFs $(>0.5)$ were determined for $\mathrm{Cd}$ in mosses and Agaricus sp., and $\mathrm{Cu}, \mathrm{Mn}$ and $\mathrm{Zn}$ in Agaricus sp. The role of $\mathrm{Cu}, \mathrm{Mn}$ and $\mathrm{Zn}$ as important nutrients was already highlighted, while the affinity of Agaricus sp. to accumulate $\mathrm{Cu}$ is well documented (Alonso et al., 2003). On the other hand, the higher BAFs obtained for $\mathrm{Ba}, \mathrm{Bi}, \mathrm{Cd}$ and $\mathrm{Pb}$ could be related to the traffic influence.

Lack of statistically significant correlation between moss and soil samples, with exception of $\mathrm{Li}$ and $\mathrm{Tl}(0.64 ; \mathrm{p}<0.05)$, suggests that the influence of soil on the element ratios in moss and mushrooms is insignificant. It is, however, conspicuous that very similar multi-element patterns were found in mosses, mushrooms and the soil samples (Fig. 2).

In addition, the lowest or minimal concentrations of most elements determined in moss sample M7 correspond to their lowest content in soil sample S7. Investigations of Reimann et al. (2001b) showed good correlations of elements between mosses and the soil O-horizon, but not with the deeper soil layers. The authors suggested greater influence of surface processes, than the substrate, on the chemical composition of mosses and the soil O-horizon. The results of this investigations support that conclusion and suggest that the soil factor most probably accounts for the majority of metal(loid)s in mushrooms and mosses in this pristine environment, while the dominant origin of elements in mosses is probably the soil dust particulates. The origin of $\mathrm{Ba}, \mathrm{Bi}, \mathrm{Cd}$ and $\mathrm{Pb}$ could be atmospheric and related to the road vicinities or distant pollution centres (cities, traffic, etc.). 

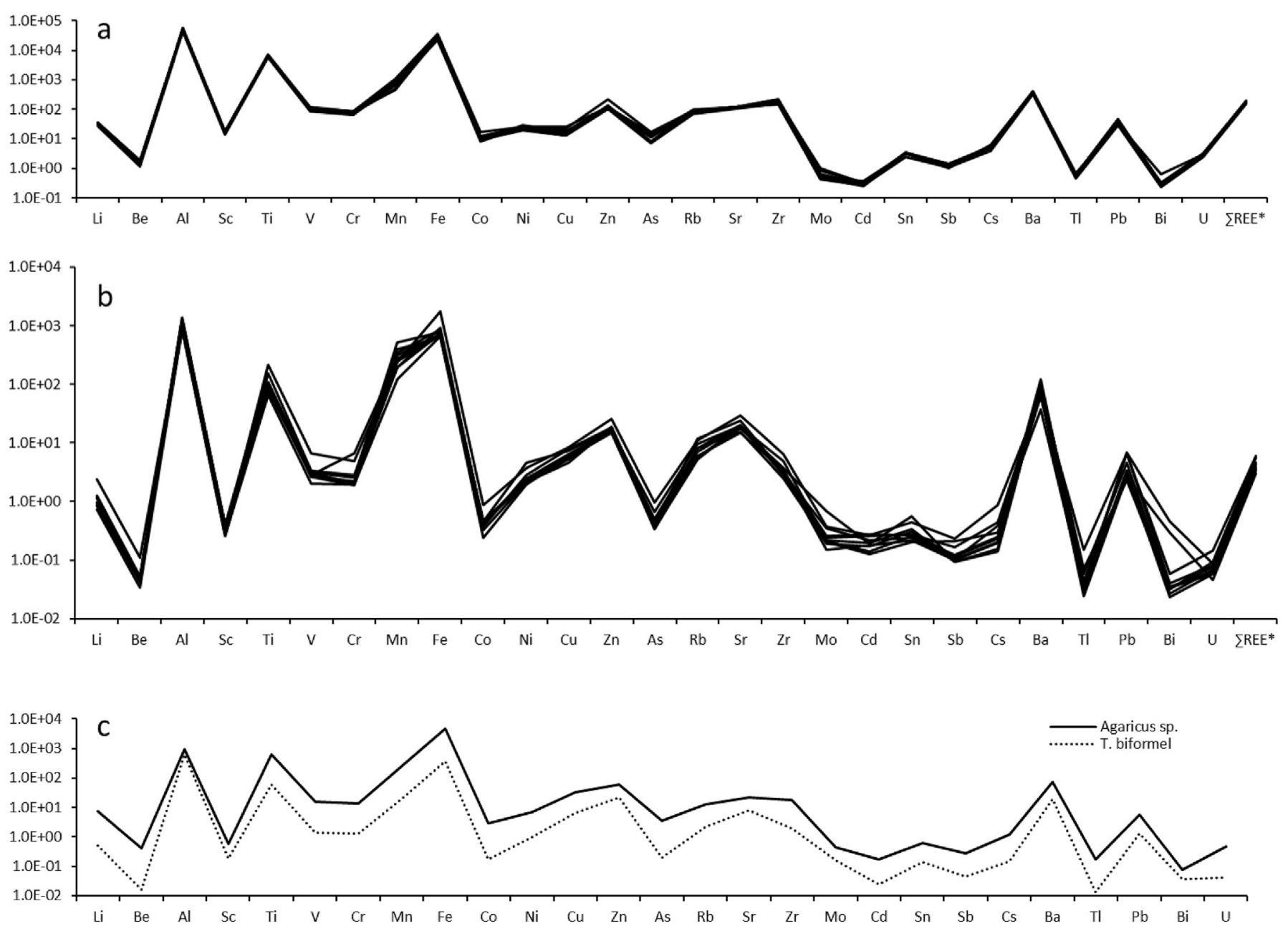

Fig. 2. The multi-element patterns in the investigated soils (a), mosses (b) and mushrooms (c). The $\sum$ REE is from Fiket et al. (2017a).

\subsection{The radionuclide activities in the Prašnik forest area}

Primordial radionuclides in soil from geogenic sources (uranium, thorium, potassium) account for the largest part of the outdoor gamma radiation, their distribution depending primarily on that of the rock they originate from and sedimentary processes, influencing their accumulation or dilution (Aközcan et al., 2014). The artificial radionuclides, ${ }^{137} \mathrm{Cs}$ and ${ }^{134} \mathrm{Cs}$, resulting from nuclear weapon tests and power plant accidents, as well as cosmogenic radionuclide, ${ }^{7} \mathrm{Be}$, are deposited from the atmosphere by wet and dry deposition and result from movement of air masses on global scales.

The activity concentrations of the measured radionuclides in soils (Table 3) varied in the range of $50.7-82.4 \mathrm{~Bq} \mathrm{~kg}^{-1}$ for ${ }^{238} \mathrm{U}$, $36.2-50.1 \mathrm{~Bq} \mathrm{~kg}{ }^{-1}$ for ${ }^{226} \mathrm{Ra}, 22.2-102 \mathrm{~Bq} \mathrm{~kg}^{-1}$ for ${ }^{210} \mathrm{~Pb}, 2.08-3.22$ for ${ }^{235} \mathrm{U}, 37.8-45.8 \mathrm{~Bq} \mathrm{~kg}{ }^{-1}$ for ${ }^{232} \mathrm{Th}, 473-621 \mathrm{~Bq} \mathrm{~kg}^{-1}$ for ${ }^{40} \mathrm{~K}$, 4.82-32.4 Bq kg ${ }^{-1}$ for ${ }^{7} \mathrm{Be}$, and $14.6-67.4 \mathrm{~Bq} \mathrm{~kg}^{-1}$ for ${ }^{137} \mathrm{Cs}$ and $0.17-4.62 \mathrm{~Bq} \mathrm{~kg}^{-1}$ for ${ }^{134} \mathrm{Cs}$.

Table 3

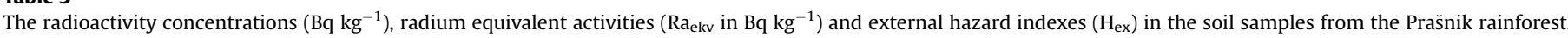

\begin{tabular}{|c|c|c|c|c|c|c|c|c|c|c|c|}
\hline Sample & $\begin{array}{l}\left.{ }^{238} \mathrm{U}^{-1}\right) \\
\left(\mathrm{Bq} \mathrm{kg}^{-1}\right)\end{array}$ & $\begin{array}{l}{ }^{226} \mathrm{Ra} \\
\left(\mathrm{Bq} \mathrm{kg}^{-1}\right)\end{array}$ & $\begin{array}{l}{ }^{210} \mathrm{~Pb} \\
\left(\mathrm{~Bq} \mathrm{~kg}^{-1}\right)\end{array}$ & $\begin{array}{l}{ }^{235} \mathrm{U} \\
\left(\mathrm{Bq} \mathrm{kg}{ }^{-1}\right)\end{array}$ & $\begin{array}{l}{ }^{232} \mathrm{Th} \\
\left(\mathrm{Bq} \mathrm{kg}^{-1}\right)\end{array}$ & $\begin{array}{l}{ }^{40} \mathrm{~K} \\
\left(\mathrm{~Bq} \mathrm{~kg}^{-1}\right)\end{array}$ & $\begin{array}{l}{ }^{7} \mathrm{Be} \\
\left(\mathrm{Bq} \mathrm{kg}^{-1}\right)\end{array}$ & $\begin{array}{l}{ }^{137} \mathrm{Cs} \\
\left(\mathrm{Bq} \mathrm{kg}^{-1}\right)\end{array}$ & $\begin{array}{l}{ }^{134} \mathrm{Cs} \\
\left(\mathrm{Bq} \mathrm{kg}^{-1}\right)\end{array}$ & $\begin{array}{l}\mathrm{Ra}_{\mathrm{ekv}} \\
\left(\mathrm{Bq} \mathrm{kg}^{-1}\right)\end{array}$ & Hex \\
\hline S1 & 50.7 & 50.1 & 38.7 & 3.22 & 43.5 & 534 & 4.82 & 14.6 & 0.69 & 154 & 0.414 \\
\hline S2 & 82.4 & 42.2 & 43.2 & 3.14 & 45.8 & 621 & 22.3 & 28.8 & 1.32 & 156 & 0.577 \\
\hline S3 & 68.0 & 43.1 & 49.2 & 2.35 & 45.8 & 598 & 32.4 & 29.8 & 4.62 & 156 & 0.422 \\
\hline S4 & 51.2 & 41.4 & 22.2 & 3.05 & 42.0 & 541 & 13.9 & 26.0 & 2.00 & 143 & 0.387 \\
\hline S5 & 80.3 & 46.8 & 97.6 & 2.52 & 41.1 & 542 & 10.1 & 46.4 & 1.03 & 147 & 0.698 \\
\hline S6 & 74.9 & 36.2 & 62.8 & 2.08 & 37.8 & 473 & 6.77 & 26.0 & 0.66 & 127 & 0.342 \\
\hline S7 & 61.4 & 45.1 & 101.8 & 2.72 & 39.0 & 511 & 8.91 & 67.4 & 1.96 & 140 & 0.379 \\
\hline S8 & 65.9 & 47.0 & 52.2 & 2.69 & 40.6 & 514 & 11.9 & 32.7 & 2.69 & 145 & 0.391 \\
\hline S9 & 62.0 & 46.4 & 40.8 & 2.59 & 42.2 & 535 & 11.8 & 21.0 & 0.40 & 148 & 0.400 \\
\hline S10 & 65.5 & 48.2 & 47.3 & 2.89 & 44.7 & 554 & 6.87 & 15.1 & 0.17 & 155 & 0.418 \\
\hline maximum & 82.4 & 50.1 & 101.8 & 3.22 & 45.8 & 621 & 32.4 & 67.4 & 4.62 & 156 & 0.698 \\
\hline minimum & 50.7 & 36.2 & 22.2 & 2.08 & 37.8 & 473 & 4.82 & 14.6 & 0.17 & 127 & 0.342 \\
\hline average & 66.2 & 44.7 & 55.6 & 2.73 & 42.3 & 542 & 13.0 & 30.8 & 1.55 & 147 & 0.443 \\
\hline
\end{tabular}


The obtained radionuclide activities of the Prašnik soil samples (Table 3) were in agreement or lower than those reported by the United Nations Scientific Committee on the Effects of Atomic Radiation UNSCEAR for Croatian soils (UNSCEAR, 2000) and other studies in the region (Durusoy and Yildrim, 2017; Guidotti et al., 2015; Mabit et al., 2012; Skoko et al., 2014; Šoštarić et al., 2017), with the exception of ${ }^{40} \mathrm{~K}$. Even though the specific activities of ${ }^{40} \mathrm{~K}$ were within the determined range prescribed by UNSCEAR (2000), the average value (542 $\mathrm{Bq} \mathrm{kg}^{-1}$, RSD 8\%) was somewhat higher than the prescribed average $\left(490 \mathrm{~Bq} \mathrm{~kg}{ }^{-1}\right)$. The obtained ${ }^{40} \mathrm{~K}$ activities were also higher compared to those found by Skoko et al. (2014) and Vaupotic et al. (2007) for the terra rossa soils. Ribeiro et al. (2018) found correlation between the radionuclide activities and soil characteristics (e.g. pH, organic matter content), and not with the bedrock composition, even though some trends between soil types and radionuclides were observed. These authors also found highest mean values of ${ }^{40} \mathrm{~K}$ in a Gleysol, i.e. wetland type of soil, with a positive correlation between ${ }^{40} \mathrm{~K}$ activities and $\mathrm{pH}, \mathrm{CEC}$ and silt, and a negative relation with the clay content. In the Prašnik forest, where Pseudogley and Eugley soils predominate, no statistically significant correlation was found between the soil characteristics, i.e. clay content, Mz, pH, LOI, CEC, SSA (Table 2) and the radionuclide activities (Table 3 ). However, the granulometric characterization showed predominance of silt in the investigated soils, while the clay content was insignificant (Table 2), which could contribute to the elevated values of ${ }^{40} \mathrm{~K}$.

The naturally occurring radionuclides, ${ }^{238} \mathrm{U},{ }^{232} \mathrm{Th}$ and ${ }^{235} \mathrm{U}$ showed low spatial variability in the soil of the Prašnik forest (RSD from $6 \%$ to $16 \%$ ). The average ${ }^{238} \mathrm{U}$ activity was well below that set by UNSCEAR (2000). Similar values in soils from the region were found by Džoljić et al. (2017), Skoko et al. (2014), Šoštarić et al. (2017) and Vaupotič et al. (2007, 2012). Due to higher specific activities of ${ }^{238} \mathrm{U}$ in several stations (S2, S3, S5 and S6), the ratio of ${ }^{238} \mathrm{U} /{ }^{226} \mathrm{Ra}$ was in disequilibrium $(1.6-2.1)$, pointing to their different mobility. Similar was found by Júnior et al. (2006), suggesting greater migration and distribution of uranium, compared to the stable radium, especially evident when distant from their main source. In all soil samples, the activities of ${ }^{238} \mathrm{U}$ were higher than ${ }^{232} \mathrm{Th}$, while the ${ }^{232} \mathrm{Th} /{ }^{226} \mathrm{Ra}$ ratio ranged from 0.9 to 1.1 .

Activities of ${ }^{137} \mathrm{Cs},{ }^{134} \mathrm{Cs},{ }^{7} \mathrm{Be}$ and ${ }^{210} \mathrm{~Pb}$ varied the most (RSD from $46 \%$ to $86 \%$ ) in the investigated soil samples. The long-lived artificial ${ }^{137} \mathrm{Cs}$ is closely monitored in soil and the fallout to prevent the food chain contamination. Compared to the activities of ${ }^{137} \mathrm{Cs}$ in a soil from the naturally protected area of Kopački rit, Croatia (average of $7.2 \pm 5.6 \mathrm{~Bq} \mathrm{~kg}^{-1}$; Lukanović et al., 2017), the activities in Prašnik were higher (average $30.8 \mathrm{~Bq} \mathrm{~kg}^{-1}$, Table 3 ), but in accordance with other studies of Croatian soils (12.6-99.8 Bq kg-1, Skoko et al., 2014). The activities of ${ }^{137} \mathrm{Cs}$ showed significant correlation with ${ }^{134} \mathrm{Cs}(0.63, \mathrm{p}<0.05),{ }^{7} \mathrm{Be}(0.69, \mathrm{p}<0.05)$, and ${ }^{210} \mathrm{~Pb}(0.75 ; \mathrm{p}<0.05)$.

In the Prašnik forest, the activities of ${ }^{210} \mathrm{~Pb}$ were significantly higher (Table 3) than those recorded by Džoljić et al. (37-64 Bq $\mathrm{kg}^{-1}, 2017$ ) and lower than Fujiyoshi et al. (2011), for forest soils from the region. Investigation of activities of ${ }^{210} \mathrm{~Pb}$ in plants and soil, performed by Džoljić et al. (2017), confirmed atmosphere as the main source of ${ }^{210} \mathrm{~Pb}$. In our study, the highest activities of ${ }^{210} \mathrm{~Pb}$ were recorded in soil samples S5 and S7, where the total Pb concentrations showed average and minimal values, respectively. These soil samples also exhibited highest activities of ${ }^{137} \mathrm{Cs}$, corroborating atmospheric deposition as important source for both of these radionuclides.

In the decay chain of ${ }^{238} \mathrm{U}$ the supported and the excess or fallout ${ }^{210} \mathrm{~Pb}$ can be distinguished. The excess part of the ${ }^{210} \mathrm{~Pb}$ is formed from the parent isotope ${ }^{222} \mathrm{Rn}$ that diffused from soil into the atmosphere, where it eventually decayed into ${ }^{210} \mathrm{~Pb}$ (Falandysz and Borovička, 2012; Fujiyoshi et al., 2011; Mabit et al., 2014). The in situ decay of ${ }^{238} \mathrm{U}$ radionuclide in soil produced the supported ${ }^{210} \mathrm{~Pb}$, from the parent radionuclide ${ }^{226} \mathrm{Ra}$. Due to the fallout ${ }^{210} \mathrm{~Pb}$, arriving from the atmosphere, there is a disequilibrium with the supported ${ }^{210} \mathrm{~Pb}$ that is already present in the soil and is in equilibrium with the ${ }^{226}$ Ra activity (Džoljić et al., 2017; Mabit et al., 2014). The fallout ${ }^{210} \mathrm{~Pb}$ is therefore determined as a difference between the total ${ }^{210} \mathrm{~Pb}$ and the ${ }^{226} \mathrm{Ra}$ activities. Increased levels of the fallout ${ }^{210} \mathrm{~Pb}$ were found in stations S5-S7. These discrepancies in the ${ }^{210} \mathrm{~Pb}$ activities in these stations, caused by the excess or the fallout ${ }^{210} \mathrm{~Pb}$, support the assumption of increased atmospheric deposition in these stations, whether through the lack of canopy or proximity to roads. However, since the ${ }^{210} \mathrm{~Pb}$ associates with particles, its origin could also be from the uplifted soil particles from the surrounding area (Mabit et al., 2014). As previously mentioned, the activities of ${ }^{210} \mathrm{~Pb}$ and ${ }^{137} \mathrm{Cs}$ were found positively correlated, while even higher correlation was established between the fallout ${ }^{210} \mathrm{~Pb}$ and ${ }^{137} \mathrm{Cs}(0.79 ; \mathrm{p}<0.05)$.

The average value of radium equivalent activity $\left(\mathrm{Ra}_{\mathrm{ekv}}\right)$ varied in the range from $127 \mathrm{~Bq} \mathrm{~kg}{ }^{-1}$ to $156 \mathrm{~Bq} \mathrm{~kg}^{-1}$, and the calculated external hazard index $\left(\mathrm{H}_{\mathrm{ex}}\right)$ values were between 0.342 and 0.698 (Table 3). The obtained values are below the recommended maximum value of $370 \mathrm{~Bq} \mathrm{~kg}{ }^{-1}$ for $\mathrm{Ra}_{\mathrm{ekv}}$ and 1 for $\mathrm{H}_{\mathrm{ex}}$, suggesting negligible radiation risk of the studied soils. From all of the above it is evident that the radionuclide activities in the Prašnik area result from the global atmospheric fall-out and the soil bedrock composition.

\section{Conclusion}

The presented research provides baseline concentrations and a complete multi-element analysis of soil and non-vascular, bioindicator species (mosses and mushrooms) in a pristine temperate rainforest.

Elements stored in plant tissue in areas distant from known anthropogenic sources provide important information on the contribution of atmospheric deposition as a source of contaminants, and are beneficial in assessing the influence of human activities on the airborne pollution. It was found that the distribution of elements in mosses and mushrooms of the Prašnik area primarily reflect the influence of the local site conditions. This is a combination of the bedrock composition, leaching and processes related to plant/mushroom physiology. Namely, biological processes in plants define the content of nutrients, while the atmospheric deposition contributed, at least partly, to levels of $\mathrm{Bi}, \mathrm{Cd}$ and $\mathrm{Pb}$.

The naturally elevated concentrations of elements in the soil from the investigated area resulted in their higher content in mosses and mushrooms, suggesting caution when using plants from pristine environments of unknown substrate geochemical composition for dietary needs, as well as importance of including soil geochemistry in these kinds of investigations. The results of the study also emphasised the need for using several bioindicator species for monitoring purposes to properly interpret all the factors affecting a particular forest ecosystem.

\section{Declarations of interest}

None.

\section{Acknowledgments}

Thanks to Krunoslav Szabo, Mario Bošnjak, and Vesna Marjanović (the company Hrvatske Šume) for their help during the fieldwork. 


\section{Appendix A. Supplementary data}

Supplementary data to this article can be found online at https://doi.org/10.1016/j.chemosphere.2018.10.108.

\section{References}

Aboal, J.R., Fernández, J.A., Boquete, T., Carballeira, A., 2010. Is it possible to estimate atmospheric deposition of heavy metals by analysis of terrestrial mosses? Sci. Total Environ. 408, 6291-6297.

Aközcan, S., Yılmaz, M., Külahcı, F.J., 2014. Dose rates and seasonal variations of ${ }^{238} \mathrm{U},{ }^{232} \mathrm{Th},{ }^{226} \mathrm{Ra}{ }^{40} \mathrm{~K}$ and ${ }^{137} \mathrm{Cs}$ radionuclides in soils along Thrace, Turkey. Radioanal. Nucl. Chem. 299, 95-101.

Alonso, J., García, M., Pérez-López, M., Melgar, M.J., 2003. The concentrations and bioconcentration factors of copper and zinc in edible mushrooms. Arch. Environ. Contam. Toxicol. 44, 180-188.

Bargagli, R., Brown, D.H., Nelli, L., 1995. Metal biomonitoring with mosses: procedures for correcting for soil contamination. Environ. Pollut. 89, 169-175.

Bašić, F., 2013. In: Hartemink, A.E. (Ed.), The Soils of Croatia, World Soil Book Series, International Union of Soil Sciences, vols. 142-144. Springer Verlag, p. 179.

Beretka, J., Mathew, P.J., 1985. Natural radioactivity of Australian building materials, industrial wastes and by-products. Health Phys. 48, 87-95.

Chiarenzelli, J., Aspler, L., Dunn, C., Cousens, B., Ozarko, D., Powis, K., 2001. Multielement and rare earth element composition of lichens, mosses and vascular plants from the Central Barrenland, Nunavut, Canada. Appl. Geochem. 16, 245-270.

Corisco, J.A.G., Mihalíka, J., Madruga, M.J., Prudêncio, M.I., Marques, R., Santos, M., Reis, M., 2017. Natural radionuclides, rare earths and heavy metals transferred to the wild vegetation covering a phosphogypsum stockpile at Barreiro, Portugal. Water Air Soil Pollut. 228, 235.

Das, N., 2005. Heavy metal biosorption by mushrooms. Nat. Rad. 4, 454-459.

Durusoy, A., Yildirim, M., 2017. Determination of radioactivity concentrations in soil samples and dose assessment for Rize Province, Turkey. J. Radiat. Res. Appl. Sci. $10,348-352$.

Džoljić, J., Stevović, S., Todorović, D., Polavder, S., Rajačić, M., Krneta-Nikolić, J., 2017. Natural and artificial radioactivity in some protected areas of southeast Europe. Nucl. Technol. Radiat. 32, 334-341.

EPA, 1999. National Research Council (US) Committee on Evaluation of EPA Guidelines for Exposure to Naturally Occurring Radioactive Materials. National Academies Press (US), Washington (DC), p. 1999.

Falandysz, J., Borovička, J., 2012. Macro and trace mineral constituents and radionuclides in mushrooms: health benefits and risks. J. Appl. Microbiol. Biotechnol. 97, 477-501.

Fernández, J.A., Carballeira, A., 2002. Biomonitoring metal deposition in Galicia (NW Spain) with mosses: factors affecting bioconcentration. Chemosphere 46, 535-542.

Fiket, Ž., Medunić, G., Furdek Turk, M., Ivanić, M., Kniewald, G., 2017a. Influence of soil characteristics on rare earth fingerprints in mosses and mushrooms: Example of a pristine temperate rainforest (Slavonia, Croatia). Chemosphere 179, 92-100.

Fiket, Ž., Mikac, N., Kniewald, G., 2017b. Mass fractions of forty-six major and trace elements, including rare earth elements, in sediment and soil reference materials used in environmental studies. Geostand. Geoanal. Res. 41, 123-135.

Filipović Marijić, V., Raspor, B., 2012. Site-specific gastrointestinal metal variability in relation to the gut content and fish age of indigenous european chub from the Sava river. Water, Air, Soil Pollut. 223 (8), 4769-4783.

Fujiyoshi, R., Yamaguchi, T., Takekoshi, N., Okamoto, K., Sumiyoshi, T., Kobal, I., Vaupotić, J., 2011. Tracing depositional consequences of environmental radionuclides $\left({ }^{137} \mathrm{Cs}\right.$ and $\left.{ }^{210} \mathrm{~Pb}\right)$ in Slovenian forest soils. Cent. Eur. J. Geosci. 3, 291-301.

Gadd, G.M., 2007. Geomycology: biogeochemical transformations of rocks, minerals, metals and radionuclides by fungi, bioweathering and bioremediation. Mycol. Res. 111, 3-49.

García, M.A., Alonso, J., Melgar, M.J., 2009. Lead in edible mushrooms: levels and bioaccumulation factors. J. Hazard Mater. 167, 777-783.

Gast, C.H., Jansen, E., Bierling, J., Haanstra, L., 1988. Heavy metals in mushrooms and their relationship with soil characteristics. Chemosphere 17, 789-799.

Guidotti, L., Carini, F., Rossi, R., Gatti, M., Cenci, R.M., Beone, G.M., 2015. Gammaspectrometric measurement of radioactivity in agricultural soils of the Lombardia region, northern Italy. J. Environ. Radioact. 142, 36-44.

Harmens, H., Norris, D.A., Steinnes, E., Kubin, E., Piispanen, J., Alber, R., Aleksiayenak, Y., Blum, O., Coșkun, M., Dam, M., De Temmerman, L., Fernández, J.A., Frolova, M., Frontasyeva, M., González-Miqueo, L., Grodzińska, K., Jeran, Z., Korzekwa, S., Krmar, M., Kvietkus, K., Leblond, S., Liiv, S., Magnússon, S.H., Maňkovská, B., Pesch, R., Rühling, Å., Santamaria, J.M., Schröder, W., Spiric, Z., Suchara, I., Thöni, L., Urumov, V., Yurukova, L., Zechmeister, H.G., 2010. Mosses as biomonitors of atmospheric heavy metal deposition: spatial patterns and temporal trends in Europe. Environ. Pollut. 158, 3144-3156.

Harmens, H., Norris, D.A., Sharps, K., Mills, G., Alber, R., Aleksiayenak, Y., Blum, O. Cucu-Man, S.-M., Dam, M., De Temmerman, L., Ene, A., Fernández, J.A., Martinez-Abaigar, J., Frontasyeva, M., Godzik, B., Jeran, Z., Lazo, P., Leblond, S., Liiv, S., Magnússon, S.H., Maňkovská, B., Pihl Karlsson, G., Piispanen, J., Poikolainen, J.,
Santamaria, J.M., Skudnik, M., Spiric, Z., Stafilov, T., Steinnes, E., Stihi, C., Suchara, I., Thöni, L., Todoran, R., Yurukova, L., Zechmeister, H.G., 2015. Heavy metal and nitrogen concentrations in mosses are declining across Europe whilst some "hotspots" remain in 2010. Environ. Pollut. 200 (2015), 93-104.

Júnior, J.A.S., Cardoso, J.J.R.F., Silva, C.M., Silveira, S.V., Amaral, R.S., 2006. Determination of radionuclides in the environment using gamma-spectrometry. Radioanal. Nucl. Chem. 269, 451-455.

Kabata-Pendias, A., 2011. Trace Elements in Soils and Plants, fourth ed. CRC Press, Taylor and Francis Group, LLC, Boca Raton, USA, p. 505.

Kalač, P., 2010. Trace element contents in European species of wild growing edible mushrooms: a review for the period 2000-2009. Food Chem. 122, 2-15.

Kalač, P., Svoboda, L., 2000. A review of trace element concentrations in edible mushrooms. Food Chem. 69, 273-281.

Kalač, P., Svoboda, L., Havlíčková, B., 2004. Contents of cadmium and mercury in edible mushrooms. J. Appl. Biomed. 2, 15-20.

Kłos, A., Czora, M., Rajfur, M., Wacławek, M., 2012. Mechanisms for translocation of heavy metals from soil to epigeal mosses. Water, Air, Soil Pollut. 22, 1829-1836.

Lazo, P., Steinnes, E., Qarri, F., Allajbeu, S., Kane, S., Stafilov, T., Frontasyeva, M.V. Harmens, H., 2018. Origin and spatial distribution of metals in moss samples in Albania: a hotspot of heavy metal contamination in Europe. Chemosphere 190, 337-349.

Lukanović, I., Poje Sovilj, M., Meštrović, T., Stanić, D., Šoštarić, M., Miklavčić, I., Babić, D., Radolić, V., Petrinec, B., 2017. In: Radolić, V., Poje Sovilj, M., Krajcar Bronić, I. (Eds.), ${ }^{137}$ Cs in Kopački Rit. Proceedings of the Eleventh Symposium of the Croatian Radiation Protection Association, pp. 261-266. Zagreb.

Mabit, L., Dornhofer, P., Martin, P., Toloza, A., Zupanc, V., 2012. Depth distribution of selected geogenic radionuclides $\left({ }^{40} \mathrm{~K},{ }^{226} \mathrm{Ra},{ }^{232} \mathrm{Th}\right)$ and anthropogenic ${ }^{137} \mathrm{Cs}$ in an undisturbed forest soil in East Slovenia. Indian J. Pure Appl. Phys. 50, 45-48.

Mabit, L., Benmansour, M., Abril, J.M., Walling, D.E., Meusburger, K., Iurian, A.R. Bernard, C., Tarján, S., Owens, P.N., Blake, W.H., Alewell, C., 2014. Fallout ${ }^{210} \mathrm{~Pb}$ as a soil and sediment tracer in catchment sediment budget investigations: a review. Earth Sci. Rev. 138, 335-351.

Markert, B., Wappelhorst, O., Weckert, V., Herpin, U., Siewers, U., Friese, K., Breulmann, G., 1999. The use of bioindicators for monitoring the heavy-metal status of the environment. J. Radioanal. Nucl. Chem. 240, 425-429.

Marović, G., Franić, Z., Senčar, J., Bituh, T., Vugrinec, O., 2008. Mosses and some mushroom species as bioindicators of radiocaesium contamination and risk assessment. Coll. Antropol. 32 (2), 109-114.

Mendil, D., Uluözlü, Ö.D., Tüzen, M., Hasdemir, E., Sarı, H., 2005. Trace metal levels in mushroom samples from Ordu, Turkey. Food Chem. 91, 463-467.

Mesić Kiš, I., Karaica, B., Medunić, G., Romić, M., Šabarić, J., Balen, D., Šoštarko, K. 2016. Soil, bark and leaf trace metal loads related to the war legacy (The Prašnik rainforest, Croatia). Min-Geol-Pet Eng. Bull. 13-28.

Nikkarinen, M., Mertanen, E., 2004. Impact of geological origin on trace element composition of edible mushrooms. J. Food Compos. Anal. 17, 301-310.

Prudêncio, M.I., 2007. Biogeochemistry of trace and major elements in a surface environment (volcanic rock, soil, mosses, lichens) in the S. Miguel Island, Azores, Portugal. J. Radioanal. Nucl. Chem. 271/2, 431-437.

Raj, Dilna Damodaran, Mohan, B., Vidya Shetty, B.M., 2011. Mushrooms in the remediation of heavy metals from soil. Int. J. Environ. Pollut Contr. Manag. 3 89-101.

Reimann, C., Koller, F., Frengstad, B., Kashulina, G., Niskavaara, H., Englmaier, P., 2001a. Comparison of the element composition in several plant species and their substrate from a 1500 000-km² area in Northern Europe. Sci. Total Environ. 278, 87-112.

Reimann, C., Kashulina, G., de Caritat, P., Niskavaara, H., 2001b. Multi-element multi-medium regional geochemistry in the European Arctic: element concentration, variation and correlation. Appl. Geochem. 16, 759-780.

Ribeiro, F.C.A., Silva, J.I.R., Lima, E.S.A., do Amaral Sobrinho, N.M.B., Perez, D.V. Lauria, D.C., 2018. Natural radioactivity in soils of the state of Rio de Janeiro (Brazil): radiological characterization and relationships to geological formation, soil types and soil properties. J. Environ. Radioact. 182, 34-43.

Salminen, R., Batista, M.J., Bidovec, M., Demetriades, A., De Vivo, B., De Vos, W. Duris, M., Gilucis, A., Gregorauskiene, V., Halamic, J., Heitzmann, P., Lima, A. Jordan, G., Klaver, G., Klein, P., Lis, J., Locutura, J., Marsina, K., Mazreku, A. O'Connor, P.J., Olsson, S.Å., Ottesen, R.T., Petersell, V., Plant, J.A., Reeder, S., Salpeteur, I., Sandström, H., Siewers, U., Steenfelt, A., Tarvainen, T., 2005. FOREGS Geochemical Atlas of Europe, Part 1: Background Information, Methodology and Maps. Geological Survey of Finland, Espoo, p. 526. Available online at: http://www.gtk.fi/publ/foregsatlas/.

Sardans, J., Peñuelas, J., 2005. Trace element accumulation in the moss Hypnum cupressiforme Hedw. and the trees Quercus ilex L. and Pinus halepensis Mill. in Catalonia. Chemosphere 60, 1293-1307.

Sesli, E., Tuzen, M., Soylak, M., 2008. Evaluation of trace metal contents of some wild edible mushrooms from Black sea region, Turkey. J. Hazard Mater. 160 462-467.

Shotyk, W., Bicalho, B., Cuss, C.W., Duke, M.J.M., Noernberg, T., Pelletier, R. Steinnes, E., Zaccone, C., 2016. Dust is the dominant source of "heavy metals" to peat moss (Sphagnum fuscum) in the bogs of the Athabasca Bituminous Sands region of northern Alberta. Environ. Int. 92-93, 494-506.

Širić, I., Kos, I., Kasap, A., Petković, F.Z., Držaić, V., 2016a. Heavy metals bioaccumulation by edible saprophytic mushrooms. J. Cent. Eur. Agric. 17 (3), 884-900.

Širić, I., Humar, M., Kasap, A., Kos, I., Mioč, B., Pohleven, F., 2016b. Heavy meta bioaccumulation by wild edible saprophytic and ectomycorrhizal mushrooms. 
Environ. Sci. Pollut. Res. 23, 18239-18252.

Skoko, B., Marović, G., Babić, D., 2014. Radioactivity in the Mediterranean flora of the Kaštela Bay, Croatia. J. Environ. Radioact. 135, 36-43.

Steinnes, E., 1995. A critical evaluation of the use of naturally growing moss to monitor the deposition of atmospheric metals. Sci. Total Environ. 160-161, $243-249$.

Steinnes, E., Berg, T., Uggerud, H.T., 2011. Three decades of atmospheric metal deposition in Norway as evident from analysis of moss samples. Sci. Total Environ. 412-413, 351-358.

Steinnes, E., Lierhagen, S., 2018. Geographical distribution of trace elements in natural surface soils: atmospheric influence from natural and anthropogenic sources. Appl. Geochem. 88 A, 2-9.

Šoštarić, M., Zgorelec, Ž., Babić, D., Šestak, I., Kisić, I., Mesić, M., Perčin, A., 2017. Radioactivity of selected agricultural soils in Croatia: effects of soil properties soil management, and geological parameters. Water, Air, Soil Pollut. 228, 218.

Sparica, M., Buzaljko, R. Jovanović, Č. 1984. Geology of Nova Gradiška Sheet (L33107). Basic Geological Map of Yugoslavia, 1:100000. Institute of Geology, Zagreb, Institute of Geology, Sarajevo, Beograd (Federal institute of Geology) (in Croatian).
Špirić, Z., Vučković, I., Stafilov, T., Trajče, S., Kušan, V., Frontasyeva, M., 2013. Air pollution study in Croatia using moss biomonitoring and ICP-AES and AAS analytical techniques. Arch. Environ. Contam. Toxicol. 65, 33-46.

Turkekul, I., Elmastas, M., Tüzen, M., 2004. Determination of iron, copper, manganese, zinc, lead, and cadmium in mushroom samples from Tokat, Turkey. Food Chem. 84, 389-392.

Tuzen, M., 2003. Determination of heavy metals in soil, mushroom and plant samples by atomic absorption spectrometry. Microchem. J. 74, 289-297.

United Nations Scientific Committee on the Effects of Atomic Radiation (UNSCEAR), 2000. Sources and effects of ionising radiation. In: Sources, Annex B: Exposure from Natural Radiation Sources . Report to the General Assembly, United Nations, New York, USA, vol. I.

Vaupotič, J., Barišić, D., Kobal, I., Lulić, S., 2007. Radioactivity and Radon potential of the terra rossa soil. Radiat. Meas. 42, 290-297.

Vaupotič, J., Žvab Rožič, P., Barišić, D., 2012. Environmental aspect of radon potential in terra rossa and eutric cambisol in Slovenia. Environ. Earth Sci. 223-229.

Wentworth, C.K., 1922. A scale of grade and class terms for clastic sediments. J. Geol. 30, 377-392. 